\title{
EFEKTIVITAS PELATIHAN "PEDE" (PEMAAFAN, EFIKASI DIRI, DAN EMPATI) UNTUK MENINGKATKAN SCHOOL WELL-BEING SISWA
}

\author{
Imam Setyawan, Endah Kumala Dewi \\ Fakultas Psikologi, Universitas Diponegoro \\ J1. Prof. Soedarto, S.H., Kampus Undip Tembalang, Semarang, Indonesia 50275 \\ imamsetyawan.psiundip@gmail.com
}

\begin{abstract}
This study aims to examine the effectiveness of PEDE training (Forgiveness, Self-Efficacy, and Empathy) to increase school well-being of students. The experimental design of this study was pretest-posttest without control group design. Participants were 50 students from vocational high schools, 21 man and 29 woman. Data were collected using School Well-Being Scale (20 items; $\alpha=.81$ ). Data were analyzed using paired sample t-test to determine the differences in the level of school well-being before and after treatment. The results of the analysis showed a significant increase in school well-being $(t(49)=3.904 ; p<.001)$ from pretest $(M=60.98 ; S D=4.162)$ to posttest $(M=63.28 ; S D=4.291)$. PEDE training (Forgiveness, Self-Efficacy, and Empathy) is proven to increase school well-being of students. Forgiveness is needed by students in facing the weaknesses and pressures they feel at school, pressure can come from within themselves, other people and the environment. Student satisfaction is inseparable from empathy, where students are able to understand and relate to cognitive and affective experiences from the perspective of others. With the various pressures and challenges faced, students need the self-efficacy to be able to succeed in achieving each of their goals, so that they receive recognition and appreciation in the school environment.
\end{abstract}

Keywords: school well-being; forgiveness; self-efficacy; empathy

\begin{abstract}
Abstrak
Penelitian ini bertujuan untuk menguji efektivitas Pelatihan PEDE (Pemaafan, Efikasi Diri, dan Empati) untuk meningkatkan school well-being siswa. Penelitian dilakukan dengan desain eksperimen pretest - posttest without control group design. Partisipan adalah siswa sekolah menengah kejuruan, berjumlah 50 orang, yang terdiri dari 21 laki-laki dan 29 perempuan, dengan rentang usia 16 - 17 tahun. Pengumpulan data dilakukan dengan menggunakan Skala School Well-being (20 aitem; $\alpha=0,81$ ). Data diolah dengan paired sample t-test untuk mengetahui perbedaan antara tingkat school well-being siswa sebelum dan sesudah perlakuan. Hasil analisis menunjukkan adanya peningkatan school well-being yang signifikan $(t(49)=3,904 ; p<0,001)$, dengan nilai rerata pretest sebesar 60,98 ( $\mathrm{SD}=4,162)$ dan nilai rerata posttest sebesar 63,28 ( $\mathrm{SD}=4,291)$. Pelatihan $\mathrm{PEDE}$ (Pemaafan, Efikasi Diri, dan Empati) terbukti meningkatkan school well-being siswa. Pemaafan diperlukan siswa dalam menghadapi kelemahan dan tekanan yang dirasakannya di sekolah, baik dari dalam diri, orang lain maupun lingkungan. Sedangkan kepuasan siswa juga tidak terlepas dari kemampuannya memahami dan berhubungan dengan pengalaman kognitif dan afektif dari sudut pandang orang lain, melalui empati. Dengan berbagai tekanan dan tantangan yang ada siswa memerlukan keyakinan diri untuk dapat berhasil mencapai setiap tujuan tugasnya sehingga mendapat pengakuan dan penghargaan di lingkungan sekolah.
\end{abstract}

Kata kunci: school well-being; pemaafan; efikasi diri; empati

\section{PENDAHULUAN}

Sekolah merupakan tempat siswa menghabiskan sebagian besar waktunya, mengerjakan berbagai aktivitas mental dan fisik, dan hasil kerja mereka diawasi oleh orang yang memiliki kedudukan lebih tinggi dengan aturan yang dijalankan secara rutin setiap hari. Kondisi fisik sekolah perlu diperhatikan agar siswa merasa nyaman dalam beraktivitas dan berada di lingkungan sekolahnya, termasuk tugas yang diberikan 
secara berulang, keterbatasan ruang belajar, ruang yang terlalu panas, kegaduhan, atau berdebu, kemungkinan terjadi kekerasan atau perkelahian, kurangnya penerangan, dan sirkulasi udara. Selain lingkungan fisik, sekolah merupakan tempat terjadinya interaksi sosial yang mengasah berbagai ketrampilan sosial yang dibutuhkan siswa dalam perkembangan pribadi.

Persepsi anak terhadap lingkungan dan dampak dari kondisi kehidupan, yang bisa berbeda dari orang dewasa (misalnya: orangtua, guru), menggarisbawahi gagasan bahwa sudut pandang berbagai perspektif perlu dipertimbangkan dalam melihat wellbeing subjektif dari anak (Ben-Arieh, McDonell, \& Attar-Schwartz, 2009). Morris (2009) bahwa well-being harus menjadi fungsi pendidikan utama, dan semua sekolah harus digerakkan untuk memaksimalkan pertumbuhan siswa dan pendidik. Indikator well-being meliputi cakupan yang cukup luas berbagai perspektif dan area, dari pengukuran kondisi objektif kehidupan anak (seperti: standar material, standar komunitas dan modal sosial) sampai pada pengukuran pengalaman hidup subjektif anak (seperti: kepuasan hidup, emosi positif) (Ben-Arieh \& Frønes, 2011). Kesejahteraan subjektif dan kontekstual yang dialami siswa muncul baik dalam afek positif, seperti persepsi kepuasan pada ranah hidup khusus (konteks sekolah), maupun afek negatif, seperti faktor psikologi yang mengindikasikan burnout dalam belajar (SalmelaAro dkk., 2009). Pengertian ini mengacu pada rasa sejahtera siswa untuk berada di dalam sekolah, terkait dengan iklim dan kehidupan sekolah. Konsep yang sesuai dalam menggambarkan keberhasilan sekolah menjadi lingkungan positif bagi tercapainya peak actualization siswa adalah school well-being (Setyawan \& Dewi, 2015).

Indikator well-being memperhatikan kebutuhan material maupun non-material dari kebutuhan dasar manusia sebagai suatu kesatuan. Allardt (Konu \& Rimpela, 2002) membagi kebutuhan-kebutuhan tersebut ke dalam tiga kategori yaitu having, loving, dan being. Having merujuk pada kondisi material dan kebutuhan impersonal dalam perspektif yang luas. Loving merupakan kebutuhan berhubungan dengan orang lain dan membentuk identitas sosial, sedangkan being merupakan kebutuhan pengembangan pribadi, seperti integrasi dalam masyarakat dan hidup secara harmonis dengan alam. Tiga kategori tersebut apabila dihubungkan dalam konteks sekolah, menjadi suatu model school well-being yang didefinisikan sebagai keadaan siswa yang mencapai kepuasan dalam pemenuhan kebutuhan kondisi sekolah (having), hubungan sosial (loving), kebutuhan pemenuhan diri (being) dan dilengkapi dengan status kesehatan (health status) di sekolah, sehingga siswa mampu mengatasi masalah-masalah psikososial maupun lingkungan.

Sekolah merupakan bangunan atau lembaga untuk belajar dan mengajar serta tempat menerima dan memberi pelajaran. Tidak sekedar bangunan, sekolah merupakan tempat terselenggaranya pendidikan formal yang memberi pembelajaran mengenai berbagai aspek dalam kehidupan. Tujuan pembelajaran di sekolah bisa tercapai bila siswa memiliki kepuasan terhadap sekolah mereka. Kepuasan tersebut berasal dari terpenuhinya kebutuhankebutuhan dasar mereka terkait kehidupan di sekolah. School well-being bermanfaat untuk membantu menciptakan lingkungan pembelajaran yang kondusif dan tercapainya tujuan pembelajaran itu sendiri, memahami factor yang mampu membuat siswa lebih senang dan puas dalam menjalani kehidupan di sekolah (Setyawan \& Dewi, 2015).

Empat aspek school well-being, bisa dijabarkan secara lebih terperinci. Aspek pertama adalah kondisi sekolah (having) yang diwakili oleh kondisi sekolah. Kondisi sekolah meliputi lingkungan fisik di sekitar sekolah dan lingkungan di dalam sekolah. Lingkungan fisik berkaitan dengan keamanan, kenyamanan, kegaduhan yang terjadi, pertukaran udara, suhu, dan sebagainya. Lingkungan di dalam sekolah mengacu pada lingkungan pembelajaran 
yang meliputi mata pelajaran dan jadwal pelajaran, serta hukuman yang diberikan kepada siswa, serta pelayanan sekolah terhadap siswa seperti pelayanan kesehatan dan konseling. Aspek kedua adalah hubungan sosial (loving), yang dalam kategori school well-being diwakili oleh hubungan sosial. Kebutuhan loving meliputi iklim sekolah, dinamika kelompok, hubungan antara guru dan murid, hubungan dengan teman sebaya, serta hubungan sekolah dengan keluarga siswa. Aspek penyusun berikutnya adalah pemenuhan diri (being), kategori ini bila diterapkan di lingkungan sekolah dapat dilihat sebagai cara sekolah dalam memberikan sarana pemenuhan diri. Setiap siswa harus dipertimbangkan sebagai anggota komunitas sekolah yang sama pentingnya. Aspek terakhir adalah status kesehatan (health status). Konu dan Rimpelä (2002) juga menyatakan bahwa kategori being dalam school well-being diwakili oleh selffulfillment yang meliputi penghargaan yang diberikan sekolah terhadap hasil kerja siswa, bimbingan dan dorongan yang diberikan oleh guru kepada siswa, peningkatan harga diri dan penggunaan kreativitas. Aspek health status terdiri dari gejala fisik dan mental, demam, penyakit serta keadaan sakit yang lain. Kemunculan gejala-gejala penyakit pada periode waktu tertentu menjadi tolak ukur dari pengukuran health status siswa. Kesehatan mental siswa juga menjadi sesuatu yang diteliti dalam kategori health status. Studi-studi terkini melaporkan bahwa siswa menunjukkan tingkat disstres psikologi yang lebih tinggi dibandingkan populasi secara umum (Eskin dkk., 2016)

Konu dan para rekannya memperkenalkan school well-being sebagai konsep yang umum (Konu \& Rimpela, 2002), termasuk di dalamnya pertanyaan tentang hubungan sosial dan tugas sekolah sebagai komponen mendasar (Konu, Alanen, Lintonen, \& Rimpela, 2002). Murray-Harvey (2010) menyatakan bahwa baik luaran akademik dan sosial/emosional, dengan jelas dipengaruhi oleh kualitas hubungan antara guru dan siswa yang jika dibandingkan dengan keluarga dan teman sebaya, memberikan pengaruh terkuat pada kesejahteraan dan hasil prestasi siswa.

Long, et.al. (2012) dalam penelitiannya memaparkan pentingnya menggunakan pendekatan kontekstual untuk melihat kesejahteraan subjektif, dengan memperhitungkan lingkungan spesifik tempat remaja tinggal. Rasa aman, pengalaman tentang perlakuan yang objektif dan memiliki guru yang suportif, berhubungan dengan tingkat kepuasan sekolah yang tinggi. Rasa keterhubungan siswa dengan sekolah memberi mediasi terhadap hubungan antara iklim yang ada di sekolah dengan luaran wellbeing yang positif (Bizumic, et.al., 2009).

Hasil penelitian Løhre, Lydersen, dan Vatten (2010) menyatakan bahwa guru memiliki peran penting dalam promosi school wellbeing. Khusus pada siswa laki-laki, penerimaan bantuan yang dibutuhkan dari guru terkait kuat dengan school well-being, demikian juga dengan tugas sekolah. Pada siswa perempuan yang kuat berperan adalah gangguan yang dialami selama pelajaran. Lingkungan belajar tanpa gangguan disimpulkan sebagai salah satu hal yang penting bagi school well-being.

Khatimah (2015) dalam hasil penelitiannya tentang pembentuk school well-being, menemukan bahwa gambaran school wellbeing pada siswa akselerasi adalah well perceived on school infrastructure, excellent individual capital, unwell learning design management, well interpersonal school interaction, well school management, dan perceived parental support.

Penelitian-penelitian sebelumnya memberi penekanan yang kuat pada sisi eksternal yang mewarnai school well-being siswa. Perhatian pada penguatan sisi internal siswa dalam membangun kesejahteraan diri di sekolah, menjadi sesuatu hal yang perlu dikaji lebih mendalam. 
Pelatihan PEDE (Pemaafan, Efikasi Diri dan Empati) berusaha meningkatkan school wellbeing siswa dari sisi internal, melalui ketiga elemen utama pelatihan. School well-being terkait erat dengan penilaian siswa atas apa yang dialami di sekolah dan ketrampilan sosialnya dalam menghadapi dan memaknai setiap kondisi yang dihadapi. Metode pelatihan dipilih, karena langsung bersentuhan dalam pengembangan ketrampilan sosial yang dibutuhkan dan terkait dengan ranah kognisi, afeksi dan psikomotor, tidak sekedar bersifat informatif belaka. Elemen pertama adalah pemaafan. Menurut Thompson dkk. (dalam Snyder \& Lopez, 2002) pemaafan adalah membebaskan diri dari kelekatan negatif dari sumber yang telah melakukan pelanggaran terhadap seseorang. Thompson menambahkan bahwa sumber pelanggaran dapat dari diri sendiri, orang lain, atau situasi yang dipandang sebagai di luar kendali seseorang. Snyder dan Lopez (2002) sependapat dengan Thompson bahwa terdapat tiga sumber yakni orang lain, diri sendiri, dan situasi yang bias dijadikan target pemaafan.

Elemen kedua adalah efikasi diri. Efikasi diri merupakan kepercayaan akan kemampuan individu untuk melaksanakan suatu tugas dalam situasi tertentu, sehingga bisa mencapai tujuan yang diharapkan (Bandura dalam Pajares, 2006). Lebih lanjut Pajares memaparkan bahwa Bandura menyampaikan tiga dimensi yang bisa digunakan untuk melihat tingkat efikasi diri, yaitu, magnitude (keyakinan individu menyelesaikan tugas), strength (keyakinan yang meliputi cakupan berbagai komponen dan tingkat kesulitan tugas yang bisa tangani) \& generality (generalisasi keyakinan pada tugas atau ranah yang lain).

Elemen ketiga adalah empati. Empati termasuk kemampuan untuk merasakan keadaan emosional orang lain, merasa simpatik dan mencoba menyelesaikan masalah, dan mengambil perspektif orang lain. Orang yang berempati mampu merasakan apa yang dirasakan orang lain dan memahami alasan mengapa orang tersebut merasa seperti itu (Azar, Darley, \& Duan dalam Baron, Branscombe \& Byrne, 2012). Empati tersusun dari dua dimensi, kognitif dan afektif (Liezt, et.al., 2011; Walter, 2012; Zaki \& Ochsner, 2012). Davis dkk. (dalam Hodgson \& Wertheimer, 2007) mengajukan model konseptual tentang empati sebagai suatu konstruk yang menjabarkan kedua komponen menjadi empat dimensi, yakni pengambilan sudut pandang (perspective taking), fantasi (fantasy), kepedulian empatik (empatic concern), dan tekanan personal (personal distress). Setyawan (2011) mengemukakan bahwa empati mampu meningkatkan kendali terhadap respon. Kendali terhadap respon membuat individu bisa membatasi jangkauan pengaruh kesulitan yang dihadapi, terhadap bagian-bagian lain kehidupannya. Kemampuan-kemampuan tersebut membuat individu mampu melihat kesulitan-kesulitan yang dihadapinya sebagai suatu hal yang positif dan mereduksi efekefek negatif yang mungkin muncul. Hasil penelitian Setyawan dan Dewi (2015) menunjukkan bahwa terdapat hubungan positif yang signifikan antara empati dan orientasi belajar mencari makna dengan school well-being. Hasil tersebut menunjukan adanya bukti empirik peran empati pada peningkatan school well-being siswa.

Tanpa disadari, siswa sering terjebak pada kekecewaan atas kekurangan dan tekanan akibat kondisi yang ada di sekolah. Emosiemosi negatif yang muncul, kemudian merusak motivasi dan kenyamanan siswa di sekolah. Siswa memerlukan pengembangan kemampuan diri untuk memaafkan kekurangan dan tekanan yang dirasakannya, baik dari dalam diri, orang lain ataupun lingkungan. Pemaafan individu terkait dengan kecenderungan munculnya strategi koping yang positif (Flanagan, Vanden Hoek, Ranters, \& Reich, 2012).

Silton, Flannely, dan Lutjen (2013) juga menyatakan dalam hasil penelitiannya, bahwa tingkat penurunan kesehatan seiring usia, bisa 
dikurangi dengan pemaafan, karena pemaafan memoderasi health benefits. Oleh karena itu, pemaafan sangat diperlukan agar emosi negatif dan konsekuensinya tidak mempercepat penurunan kesehatan individu sendiri.

Faktor sosial dinilai berpengaruh besar terhadap kepuasan hidup seseorang. Keyes \& Waterman (dalam Bornstein, Davidson, Keyes \& Moore, 2003) memaparkan bahwa hasil penelitian menunjukkan individu yang lebih sering terlibat dalam hubungan sosial serta memiliki peran sosial memiliki tingkat kepuasan dalam hidup yang lebih tinggi. Studi lebih lanjut menunjukkan peran sosial individu di lingkungan tempat dirinya berada, dapat meningkatkan well-being dan menurunkan tingkat stress yang dimiliki.

Salah satu kemampuan yang dibutuhkan dalam membangun hubungan sosial yang efektif adalah kemampuan untuk memahami dan berhubungan dengan pengalaman kognitif dan afektif dari orang lain. Kemampuan tersebut didefinisikan Wothington dan Wade (dalam Hodgson \& Wertheimer, 2007) sebagai empati. Empati membuat individu mampu memahami emosi orang lain dan mendorong munculnya perilaku prososial (Ang \& Goh, 2010).

Hal penting dalam pencapaian kesejahteraan individu di sekolah tergambar juga pada aspek pemenuhan diri (being) yang tidak bisa lepas dari keyakinan diri. Bandura (dalam Alwisol, 2017) menggambarkan keyakinan diri sebagai kepercayaan terhadap diri sendiri dalam melakukan suatu tindakan guna menghadapi suatu situasi sehingga dapat memperoleh hasil seperti yang diharapkan. Keyakinan diri adalah bagian dari diri (self) yang dapat mempengaruhi jenis aktivitas yang dipilih, besarnya usaha yang akan dilakukan oleh individu dan kesabaran dalam menghadapi kesulitan. Keyakinan diri merupakan kepercayaan individu mengenai kemampuannya untuk mengatasi kesulitan. Menurut Myers (dalam Setyawan, 2010) individu yang memiliki keyakinan diri yang tinggi akan mengalami sensasi atau perasaan bahwa dirinya kompeten dan efektif, yaitu mampu melakukan sesuatu dengan hasil yang baik.

Tujuan umum dari penelitian ini adalah membuktikan secara empirik efektivitas Pelatihan PEDE dalam meningkatkan school well-being siswa. Hipotesis penelitian yang menunjukkan efektivitas dari Pelatihan PEDE, adalah terdapat perbedaan yang signifikan school well-being siswa sebelum dan sesudah pelatihan. School well-being siswa setelah pelatihan lebih tinggi dari sebelum pelatihan.

\section{METODE}

Desain penelitian eksperimen yang digunakan adalah desain eksperimen kuasi dengan pretest-posttest without control group design. Tahap pertama yang dilakukan adalah melakukan pengukuran school well-being pada kelompok eksperimen. Tahap kedua, pemberian perlakuan berupa Pelatihan PEDE. Tahap ketiga dilakukan pengukuran kembali school well-being setelah perlakuan. Tahap terakhir adalah melakukan analisis komparatif antara hasil pretest dan posttest untuk melihat efektivitas perlakuan dan keterjawaban tujuan penelitian.

Terdapat dua variabel utama dalam penelitian ini. Pertama, variabel tergantung, yaitu school wellbeing, dan variabel bebas, pelatihan PEDE. School wellbeing adalah penilaian siswa terhadap kepuasan dalam pemenuhan kebutuhan dasar siswa di sekolah yang mencakup kondisi sekolah, hubungan sosial, kebutuhan pemenuhan diri dan kesehatan, dalam kehidupan sekolah yang dijalani. Pelatihan PEDE adalah serangkaian prosedur modifikasi perilaku yang didasarkan pada pembentukan kemampuan pemaafan, efikasi diri dan empati, melalui pemberian materi, game interaktif, diskusi dan simulasi.

Pelatihan dilakukan selama dua hari, masingmasing bagian (pemaafan, efikasi diri dan empati) terdiri dari tiga sesi, dengan durasi selama kurang lebih 90 menit untuk setiap 
sesi. Tiga sesi utama tersebut dibuka dengan sesi pengungkapan masalah yang dirasakan siswa di sekolah.

Pada hari pertama (setelah pendaftaran ulang peserta, perkenalan dan pembuka), bagian awal dimulai dengan "Aku dan Sekolah". Bagian pembuka tersebut berisi pengungkapan berbagai problematika utama di sekolah yang mengganggu siswa, dan pemahaman akan pentingnya perasaan nyaman dalam menjalani dinamika sekolah. Pembuka ini menjadi penting untuk melihat berbagai masalah siswa, dan menjadi dasar pemecahan masalah yang akan menjadi topik dan dikelola melalui tiga bagian utama selanjutnya. Pemahaman tentang pentingnya kenyamanan dan kebahagiaan menjalani dinamika di sekolah membuka kesadaran bahwa kesejahteraan diri adalah bagian penting yang terkadang tidak disadari oleh siswa.

Bagian "Aku dan Kau" yang merepresentasikan Empati diberikan selanjutnya, untuk membuka wawasan dan kesadaran siswa tentang sinkronisasi perspektif pribadi dan perspektif orang lain dalam memahami dan menyelesaikan setiap tantangan di sekolah. Kesadaran tentang pentingnya efektifitas interaksi dan penerimaan sosial juga dibentuk di bagian ini. Hari kedua, diteruskan dengan bagian "Aku Menerima dan Memaafkan", yang menggodok tentang kemampuan menerima, menghayati dan melepaskan perasaanperasaan negatif yang muncul dari setiap masalah. Bagian ini juga menekankan sisi-sisi positif yang bisa diterima melalui pemaafan pada diri, orang lain dan berbagai kondisi yang menjadi sumber rasa sakit.

Penerimaan diri, orang lain dan kondisi yang dihadapi, dilengkapkuati dengan bagian "Aku Bisa" yang membentuk keyakinan diri tentang kemampuan, ketrampilan dan usaha yang dilakukan siswa dalam menyelesaikan berbagai tugas sekolah dan tantangantantangan yang menyertai. Bagian utama terakhir ini juga memberikan alternatif bagi siswa dalam usaha mempertahankan dan meningkatkan keyakinan diri.

Subjek adalah siswa Sekolah Menengah Kejuruan di Kabupaten Grobogan, Jawa Tengah, berjumlah 50 orang siswa kelas $\mathrm{X}$. Subjek terdiri dari 21 laki-laki dan 29 perempuan, berusia 16 - 17 tahun, yang diperoleh dengan cluster sampling tanpa randomisasi, sebagai kelompok eksperimen (tanpa kelompok kontrol).

Pengumpulan data dilakukan dengan Skala School Wellbeing (Setyawan \& Dewi, 2015), yang terdiri dari 20 aitem, dengan reliabilitas $\alpha=0,81$. Model skala yang digunakan untuk mengukur variabel penelitian adalah model skala Likert. Data diolah dengan uji statistic paired sample $t$ test untuk mengetahui perbedaan antara tingkat school wellbeing siswa sebelum dan sesudah perlakuan.

\section{HASIL DAN PEMBAHASAN}

Hasil uji hipotesis dengan paired sample $t$ test, menunjukkan adanya peningkatan school well-being pada siswa $(\mathrm{t}=-3,904, \mathrm{p}<0,001)$ dari saat pretest $(M=60,98 ; S D=4,162) \mathrm{ke}$ posttest ( $M=63,28 ; S D=4,291)$. Hasil tersebut menunjukkan bahwa pelatihan PEDE (Pemaafan, Efikasi Diri dan Empati) efektif meningkatkan school well-being siswa. Ketiga kemampuan dan ketrampilan sosial tersebut berkontribusi dalam penyesuaian diri serta pemenuhan kesejahteraan siswa, di setiap dinamika yang ditemuinya di sekolah.

Pemaafan diperlukan siswa dalam menghadapi kekurangan dan tekanan yang dirasakannya disekolah, baik dari dalam diri, orang lain maupun lingkungan. Hal tersebut terjadi karena pemaafan berhubungan dengan penurunan stress yang berujung pada penurunan tanda-tanda gangguan mental (Toussaint, Shields, \& Slavich, 2016). Pemaafan di sekolah dapat meningkatkan school well-being siswa, karena menurut Rijavec, Jurcec, dan Olear (2013) pemaafan dapat meningkatkan well-being dengan mengantar individu mencapai kepuasan hidup 
yang lebih baik dan mengurangi perasaan negatif. Tekanan yang dialami oleh siswa sebagai remaja, baik dari orang lain ataupun kondisi sekolah, tidak menjadi akumulasi terpendam berbentuk emosi-emosi negatif, tapi tersalurkan dengan positif, bagi dirinya dan sikap terhadap transgresornya, sehingga tidak hanya menghilangkan keinginan untuk membalas menyakiti, tapi juga mengubahnya pada perasaan dan perilaku positif penuh kasih sayang (Setyawan, 2017).

Sedangkan well-being siswa juga tidak terlepas dari kemampuannya memahami dan berhubungan dengan pengalaman kognitif dan afektif dari sudut pandang orang lain, melalui empati. Gleason, dkk. (dalam Baron, Branscombe, \& Byrne, 2012) merumuskan bahwa remaja yang memiliki akurasi empati, cenderung memiliki ketrampilan everyday mind-reading, artinya, remaja semakin akurat dalam memahami apa yang dipikirkan dan dirasakan orang lain. Empati adalah proses sosial kognitif yang dibutuhkan bagi fungsi relasi yang sehat (Morrison, Mateen, Brozovich, \& Zaki, 2019). Decety dan Cowell (2014) menguatkan pendapat tersebut, dengan menjabarkan empati sebagai kemampuan untuk berbagi dan memahami pengalaman orang lain sebagai pembelajaran, dan merupakan keterampilan dasar yang mengarahkan kehidupan sehari-hari. Remaja dapat memberikan respon yang lebih tepat dalam menjalin relasi dengan orang lain dan melakukan penyesuaian yang lebih baik. Melalui emphatic joy, siswa juga akan merasa nyaman, bila bisa memiliki efek positif untuk orang lain di sekolah, artinya karena mengetahui adanya dampak positif dari empatinya pada orang lain di sekolah, maka siswa merasakan kepuasan. Mereka juga tidak akan mengalami bullying atau disisihkan secara sosial, tetapi dapat menjalin persahabatan secara memuaskan. Matangnya kemampuan empati membuat siswa sebagai individu mampu menilai diri sendiri, memahami diri dan apa yang dimilikinya sebagai pribadi, sehingga memiliki konsep diri yang kuat, sebagai dasar keyakinan terhadap tugas (Setyawan, 2010).
Dengan berbagai tekanan dan tantangan yang ada siswa memerlukan keyakinan diri untuk dapat berhasil mencapai setiap tujuan tugasnya, sehingga mendapat pengakuan dan penghargaan di lingkungan sekolah. Individu dengan efikasi diri tinggi, mampu mengelola dirinya agar terhindar dari berbagai hal yang menyimpang, dengan keyakinan bahwa dirinya memiliki kemampuan untuk memecahkan masalahnya, dan mencapai tujuan (Nora \& Zhang, 2010; Salami \& Ogundokun, 2009). Penelitian Cicognani (2011) terhadap 342 remaja menemukan bahwa keyakinan diri sebagai sumber koping, membantu remaja bertahan dari stres minor, mendorong kesejahteraan psikologis dan dukungan sosial. Siswa dengan efikasi diri tinggi lebih suka mastery goals yang mensyaratkan tantangan dan pengetahuan baru, serta performance goals yang menekankan nilai bagus dan hasil melampaui prestasi siswa lain. Dengan efikasi diri, siswa mampu menganalisis dan mengendalikan impuls mereka dan berkembang dalam menghadapi tantangan, sehingga mereka unggul secara akademis (Köseoglu, 2015). Caprara, Steca, Gerbino, Paciello, dan Vecchio, (2006), berdasarkan hasil penelitiannya menjelaskan bahwa efikasi diri pada remaja mampu mempengaruhi kesejahteraannya dalam mengatur pengalaman emosi positif, agar tetap tercipta kepuasan dalam dirinya. Efikasi diri membuat remaja mampu meyakinkan kondisinya dengan lebih baik, memiliki penerimaan diri yang baik, serta memiliki harapan yang positif tentang masa depan. Pentingnya efikasi diri juga ditekankan oleh Dave, Tripathi, Singh dan Udainiya (2011) yang menyatakan bahwa tingkat kesejahteraan dipengaruhi oleh efikasi diri, karena keyakinan mempengaruhi perilaku individu. Efikasi diri juga memiliki peran sebagai prediktor langsung bagi nilai (makna) tugas bagi siswa (Azar dkk., 2010; Keskin, 2014). Sehingga jika siswa merasa memiliki persepsi positif terhadap kemampuannya, maka siswa akan lebih mampu melakukan kegiatannya di sekolah, serta mendapatkan prestasi dan hasil akademis yang baik (Lee \& Kung, 2018). 
Tabel 3.

Uji Beda Aspek School Well-Being

\begin{tabular}{lccccc}
\hline Aspek & $\begin{array}{c}\text { Rerata } \\
\text { Pretest }\end{array}$ & $\begin{array}{c}\text { Rerata } \\
\text { Posttest }\end{array}$ & Gain Score & $t$ & $P$ \\
\hline Having & 14,82 & 15,40 & 0,580 & $-2,104$ & 0,041 \\
Loving & 13,30 & 14,06 & 0,760 & $-2,328$ & 0,024 \\
Being & 14,10 & 14,82 & 0,720 & $-2,627$ & 0,011 \\
Health Status & 13,46 & 13,78 & 0,320 & $-0,831$ & 0,410 \\
\hline
\end{tabular}

Uji beda yang dilakukan pada skor school well-being di setiap aspek menunjukkan hasil secara umum menunjukkan adanya peningkatan setelah pelatihan PEDE dilakukan. Hasil agak berbeda ditunjukkan pada aspek health status yang tetap memperlihatkan perbedaan antara skor sebelum dan sesudah, namun perbedaan tersebut tidak cukup signifikan, sedangkan aspek having, loving dan aspek being menunjukkan perbedaan yang signifikan. Tabel 3 juga menunjukkan bahwa aspek having pada subjek penelitian memiliki rerata tertinggi dari aspek yang lain, baik sebelum maupun sesudah pelatihan. Namun demikian, peningkatan rerata tertinggi justru ditunjukkan oleh aspek loving.

Kebutuhan impersonal dan kondisi material dalam cakupan luas, yang menjadi rujukan pemenuhan aspek having, terpenuhi dari kelengkapan sarana, prasarana dan fasilitas yang ada di sekolah. Apalagi penilaian fisik terhadap ketersediaan tersebut terwakili dalam nilai A pada akreditasi sekolah. Bagaimana siswa memberikan penilaian subjektif mengenai fasilitas sekolah dan pelayanan yang diharapkan bisa mendukung proses belajar mengajar di sekolah, sangatlah penting. Karena ketersediaan fasilitas sekolah yang memadai diharapkan mampu membuat siswa memiliki rasa puas pada lingkungan belajarnya (Owoeye \& Yara, 2011). Hasil penelitian Cuyvers, Weerd, Dupont, Mols, dan Nuytten (2011) pada siswa sekolah menengah atas di Flemish, Belgia menunjukkan well being yang rendah pada siswa di sekolah dengan kualitas infrastruktur yang rendah, dan sebaliknya. Penelitian tersebut dengan tegas menggarisbawahi bahwa kualitas infrastruktur sekolah jelas mempunyai dampak yang besar terhadap persepsi siswa pada kesejahteraannya. Sangat wajar bila pada Pelatihan PEDE, baik sebelum ataupun sesudah perlakuan, aspek having tetap menunjukkan rerata yang paling tinggi dari aspek lainnya.

Peningkatan rerata tertinggi ditunjukkan aspek loving sebagai representasi hubungan sosial. Membangun hubungan dengan orang lain di sekolah, tidak bisa lepas dari bagaimana individu merespon emosi orang lain, yang dipengaruhi oleh empati, sebagai salah satu aspek kognisi sosial (Spreng, McKinnon, Mar, \& Levine, 2009). Sifat multidimensional empati melibatkan ranah kognitif dan afektif (Davis, 1983; Miklikowska, Duriez, \& Soenens, 2011). Aspek perspective taking dari empati (Davis, 1983; Setyawan, 2011) merupakan kekuatan untuk memahami kondisi dan situasi serta pola pikir orang lain, yang menjadi salah satu kunci efektifitas hubungan sosial. Hubungan sosial juga bisa terjalin dengan baik dan meningkat efektifitasnya melalui pemaafan terhadap kesalahan, kekurangan dan tekanan yang diberikan oleh orang lain atau situasi social di sekolah, dengan kesediaan melepaskan perilaku kognitif dan afektif negatif menjadi perilaku kognitif dan afektif yang lebih positif. Empati dan pemaafan memperkuat kesejahteraan melalui peningkatan aspek loving yang didapat dari penerimaan individu lain dalam interaksi sosial di sekolah. 


\section{SIMPULAN}

Pelatihan PEDE (Pemaafan, Efikasi Diri dan Empati) terbukti efektif meningkatkan school well-being siswa. Siswa dan sekolah bisa menggunakan Pelatihan PEDE untuk mempertahankan dan meningkatkan school well-being siswa, sehingga juga bisa berdampak positif pada peningkatan prestasi siswa di sekolah. Peningkatan efikasi diri bisa dilakukan dengan terus mengasah serta mengembangkan kompetensi siswa melalui perilaku akademik tertentu (seperti, umpan balik yang detail terhadap tugas), konseling serta intervensi psikologis (Bresó, Schaufeli, \& Salanova, 2011), sehingga yakin dengan kemampuannya untuk menyelesaikan masalah dan mencapai tujuan. Empati juga akan berkembang dengan baik bila ditingkatkan interaksi sosial positif sehingga siswa mampu dengan tepat mengenali perasaan dan sudut pandang orang lain. Kemampuan siswa untuk lebih melihat sisi positif dari suatu kejadian dan atau situasi di sekolah akan membantu juga meningkatkan pemaafan pada diri siswa. Dengan terus menjaga akselerasi dan keseimbangan ketiga kemampuan tersebut, akan melahirkan kepuasan siswa di sekolah dalam bentuk peningkatan school well-being.

\section{DAFTAR PUSTAKA}

Alwisol. (2017). Psikologi kepribadian. Malang: UMM Press.

Ang, R. P. \& Goh, D. H. (2010). Cyberbullying among adolescents: The role of affective and cognitive empathy, and gender. Child Psychiatry and Human Development, 41, 387-397.

Azar H. K., Lavasani M. G., Malahmadi E., Amani J. (2010). The role of selfefficacy, task value, and achievement goals in predicting learning approaches and mathematics achievement. Procedia Social and Behavioral Sciences, 5, 942-947. doi:10.1016/j.sbspro.2010.07.214
Baron, R.A., Branscombe, N.R. \& Byrne, D.R. (2012). Social psychology. USA: Pearson Education, Inc.

Ben-Arieh, A., \& Frønes, I. (2011). Taxonomy for child well-being indicators: A framework for the analysis of the well-being of children Asher. Childhood, 18, 460-476. doi:10.1177/0907568211398159

Ben-Arieh, A., McDonell, J., \& AttarSchwartz, S. (2009). Safety and homeschool relations as indicators of children well being: Whose perspective counts? Social Indicators Research, 90, 339-349. doi:10.1007/s11205-0089267-y

Bizumic, B., Reynolds, K. J., Turner, J. C., Bromhead, D., \& Subasic, E. (2009). The role of the group in individual functioning: School identification and the psychological well-being of staff and students. Applied Psychology: An International Review, 58, 171-192. doi:10.1111/j.1464-0597.2008.00387.x

Bornstein, M. H., Davidson, L., Keyes, C. L. M., Moore, K. A. (2003). Well-being: Positive development across the life course. New Jersey: Lawrence Erlbaum Associates, Inc.

Bresó, E., Schaufeli, W. B., \& Salanova, M. (2011). Can a self-efficacy-based intervention decrease burnout, increase engagement, and enhance performance? A quasi- experimental study. Higher Education, 61, 339-355. https://doi.org/10.1007/s107340109334-6.

Caprara G.V., Steca P., Gerbino M., Pacielloi M., Vecchio G.M. (2006). Looking for adolescents' well-being: self-efficacy beliefs as determinants of positive thinking and happiness. Epidemiol Psichiatr Soc, 15(1), 30-43 
Cuyvers, C., Weerd, G.D., Dupont, S., Mols, S. \& Nuytten, C. (2011). Wellbeing at school: Does infrastructure matter? CELE Exchange, 10, 1-5, diunduh 30 Maret 2019 , www.researchgate.net/publication/254 439615_Well-

Being_at_School_Does_Infrastructure _Matter

Cicognani, E. (2011). Coping strategies with minor stressors in adolescence: Relationships with social support, selfefficacy, and psychological wellbeing. Journal of Applied Social Psychology, 41(3), 559-578

Dave, R., Tripathi, K. N., Singh, P., \& Udainiya, R. (2011). Subjective wellbeing, locus control and general seflefficacy among university students. Amity Journal of Applied Psychology, 2(1), 28-32.

Davis, M.H. (1983). Measuring individual differences in empathy: Evidence for multidimensional approach. Journal of Personality and Social Psychology, $44 b(5), 113-126$.

Decety, J., \& Cowell, J. M. (2014). Friends or foes: Is empathy necessary for moral behavior? Perspectives on Psychological Science, 9, 525-537. http://dx.doi.org/10.1177/17456916145 45130

Eskin, M., Sun, J. M., Abuidhail, J., Yoshimasu, K., Kujan, O., Janghorbani, M., ... Hamdan, M. (2016). Suicidal behavior and psychological distress in university students: A 12-nation study. Archives of Suicide Research, 20, 369388.

https://doi.org/10.1080/13811118.2015 .1054055 .

Flanagan, K. S., Vanden Hoek, K. K., Ranter, J. M., \& Reich, H. A. (2012). The potential of forgiveness as a response for coping with negative peer experiences. Journal of Adolescence, $35,1215-1223$.

Hodgson, L. K., \& Wertheim, E. H. (2007). "Does good emotion management and forgiveness aid forgiving? Multiple dimentions of empathy, emotion management, and forgiveness of self and others". Journal of Social and Personal Relationship, 24(6), 931-949.

Keskin H. K. (2014). A path analysis of metacognitive strategies in reading, self-efficacy and task value. International Journal of Social Sciences and Education, 4, 798-808

Khatimah, H. (2015). Gambaran school wellbeing pada peserta didik program kelas akselerasi di SMA Negeri 8 Yogyakarta. Psikopedagogia, 4(1), 20 30.

Konu, A., \& Rimpela, M. (2002). Well-being in schools: A conceptual model. Health Promotion International, 17, 79-87.

Konu, A., Alanen, E., Lintonen, T., \& Rimpela, M. (2002). Factor structure of the school well-being model. Health Education Research, 17, 732-742.

Köseoglu, Y. (2015). Self-Efficacy and Academic Achievement - A Case From Turkey. Journal of Education and Practice, 6(29), 131-141.

Lee, C. Y., \& Kung, H. Y. (2018). Math selfconcept and mathematics achievement: Examining gender variation and reciprocal relations among junior high school students in Taiwan. Eurasia Journal of Mathematics, Science and Technology Education, 14, 1239-1252. https://doi.org/10.29333/ejmste/82535.

Lietz, C. A., Gerdes, K. E., Sun, F., Geiger, J. M., Wagaman, M. A., \& Segal, E. A. (2011). The Empathy Assessment Index 
(EAI): A confirmatory factor analysis of a multidimensional model of empathy. Journal for the Society of Social Work and Research, 2(2), 104124.

Løhre, A., Lydersen, S., \& Vatten, L.J. (2010). School wellbeing among children in grades $1-10$. BMC Public Health, 10, 526-534

Long, R.F., Huebner E.S., Wedell, D.H., \& Hills, K.J. (2012). Measuring schoolrelated subjective well-being in adolescents. American Journal of Orthopsychiatry, 82(1):50-60

Miklikowska, M., Duriez, B., \& Soenens, B. (2011). Family roots of empathy related characteristics: The role of perceived maternal and paternal need support in adolescence.

Developmental Psychology, 47(5), 1342. http://dx.doi.org/10.1037/a0024726

Morris, I. (2009). Teaching happiness and wellbeing in schools. New York: Mixed Souces.

Morrison, A.S., Mateen, M.A., Brozovich, F.A. \& Zaki, J. (2019). Changes in Empathy Mediate the Effects of Cognitive-Behavioral Group Therapy but Not Mindfulness-Based Stress Reduction for Social Anxiety Disorder. Behavior Therapy, 56, 1098-1111.

Murray-Harvey, R. (2010). Relationship influences on students' academic achievement, psychological health and well-being at school. Educational and Child Psychology, 27(1), 104-115.

Nora, W. L. Y., \& Zhang. K. C. (2009). Motives of cheating among secondary student: The role of self-efficacy and peer influence. Asia Pacific Education Review, 11 , 573-584 doi:10.1007/s12564-010-9104-2.
Owoeye, J.S \& Yara, P.O. (2011). School facilities and academic achievement of secondary school agricultural science in ekiti state, nigeria. Journal of Asian Social Science, 7, 64-74.

Pajares, F. (2006). Self-efficacy during childhood and adolescence: Implications for teacher and parents, 339-367. Dalam Pajares, Frank. 2006. Self-efficacy and adolescents. New York: Information Age Publishing, Inc.

Rijavec, M., Jurcec, L., \& Olcar, D. (2013). Forgiveness, motivation to forgive and well-being. Društvena istraživanjaCasopis za opca društvena pitanja, 1, 23-40.

Salami, S.O. \& Ogundokun, M.O. (2009). Emotional intelligence and self-efficacy as predictors of academic performance. Perspectives in Education, 25(3), 175185.

Salmela-Aro, K., Kiuru, N., Leskinen, E., \& Nurmi, J. (2009). School Burnout Inventory (SBI): Reliability and validity. European Journal of Psychological Assessment, 25, 48-57.

Setyawan, I. (2010). Peran Kemampuan Empati pada Efikasi Diri Mahasiswa Peserta Kuliah Kerja Nyata PPM POSDAYA. Prosiding. Konferensi Nasional II Ikatan Psikologi Kinis: Intervensi Psikologis untuk Meningkatkan Kualitas Hidup Masyarakat Indonesia. Yogyakarta: Kanisius.

Setyawan, I. (2011). Peran ketrampilan belajar kontekstual dan kemampuan empati terhadap adversity intelligence pada mahasiswa. Jurnal Psikologi Undip, 9(1) 40-49.

Setyawan, I., \& Dewi, K. S. (2015). Kesejahteraan sekolah ditinjau dari orientasi belajar mencari makna dan 
kemampuan empati siswa sekolah menengah atas. Jurnal Psikologi Undip, 14(1), 9-20

Setyawan, I. (2017). Peran kelekatan pada orang tua pada pemaafan siswa SMP. Proyeksi, 12(2), 1-8.

Silton, N. R., Flannelly, K. J., \& Lutjen, L. J. (2013). It pays to forgive! Aging, forgiveness, hostility, and health. Journal of Adult Development, 20, 222231. http://dx.doi.org/10.1007/s10804013-9173-7.

Snyder \& Lopez. (2002). Handbook of positive psychology. New York: Oxford University Press.

Spreng, R. N., McKinnon, M. C., Mar, R.A., \& Levine, B. (2009). The toronto empathy questionnaire: Scale development and initial validation of a factor-analytic solution to multiple empathy measures. Journal of personality assessment, 91(1), 62-71. http://dx.doi.org/10.1080/00223890802 484381.

Toussaint, L. L., Shields, G. S., \& Slavich, G. M. (2016). Forgiveness, stress, and health: A 5-week dynamic parallel process study. Annuals of Behavioral Medicine, 1-9.

Walter, H. (2012). Social cognitive neuroscience of empathy: Concepts, circuits, and genes. Emotion Review, 4(1), 9-17. https://doi.org/10.1177/175407391142 1379.

Zaki, J., \& Ochsner, K. N. (2012). The neuroscience of empathy: Progress, pitfalls and promise. Nature Neuroscience, 15(5), 675-680. https://doi.org/10.1038/nn.3085 